\title{
Metode Ekstraksi Sarang Semut (Myrmecodia Pendans) dengan Teknik Maserasi untuk Menghasilkan Obat Alternatif Kanker Paru
}

\section{Extraction Methode of Myrmecodia Pendans with Maceration Techniques to Produce an Alternative Drug for Lung Cancer}

\author{
Suharyanto ${ }^{1}$ dan Bambang Purwono ${ }^{2}$ \\ ${ }^{1}$ suharyanto294@Yahoo.com, ${ }^{2}$ Purwono.bambang@ugm.ac.id \\ ${ }^{1}$ Akademi Farmasi Nasional Surakarta, Jalan Yos Sudarso no 338 Surakarta \\ 2 Jurusa Kimia FMIPA-Universitas Gadjah Mada Yogyakarta, Jalan Sekip Utara Yogyakarta
}

\begin{abstract}
Abstrak
Kanker adalah pertumbuhan sel pada berbagai jaringan dalam tubuh, sebagian besar tumbuh pada jaringan sel induknya.Setiap tahun dijumpai hampir 6 juta penderita baru yang diketahui mengidap kanker, dan lebih dari 4 juta diantaranya meninggal. Sampai saat ini pengobatan kanker dilakukan dengan 3 cara yaitu radiasi, pembedahan dan pengobatan menggunakan bahan kimia anti kanker. Akan tetapi ketiga pengobatan sebagaian besar memberikan efek samping terhadap pasien. Penelitian ini bertujuan untuk melakukan serangkaian uji pra klinis untuk menentukan dosis yang optimal Sarangsemut (Myrmecodia pendens )yang dapat digunakan sebagai obat kanker paru. Tujuan khusus dari penelitian ini adalah melakukan ekstraksi umbi Sarangsemut (Myrmecodia pendens) untuk menghasilkan obat alternatif kanker. Manfaat penelitian ini adalah dapat digunakan secara langsung oleh masyarakat sebagai obat herbal untuk terapi kanker. Uji ini dilakukan dengan menggunakan tikus putih yang diinduksi dengan DMBA (Dimethylbens (a) anthracene) dengahn dosis $20 \mathrm{mg} / \mathrm{kgBB}$ sebanyak 10 kali sebagai model. Terapi dilakukan dengan menginduksi ekstraks Sarangsemut dengan dosis $250 \mathrm{mg} / \mathrm{kgBB}$, $500 \mathrm{mg} / \mathrm{kgBB}$ dan $750 \mathrm{mg} / \mathrm{kgBB}$. Berdasarkan uji Histopatologi dapat disimpulkan bahwa sel yang mengalami kerusakan akibat penambahan DMBA dapat diperbaiki dengan ekstrak Sarangsemut dosis $750 \mathrm{mg} / \mathrm{kgBB}$.
\end{abstract}

Kata kunci : Sarangsemut, Histopathologi , kanker Paru.

\begin{abstract}
Cancer is a growing cells of any type of cell and tissue in the body anywhere, a large number of diseases are characterized by tissue and cell type of origin. Each year found nearly 6 million new patients known to have cancer, and more than 4 million of them died. Until now cancer treatment is done by 3 ways: surgery, radiation, and drug delivery of anti -neoplastic or anti- cancer. However, all three treatments over a lot of side effects to the patient. This study aims to conduct a series of pre-clinical trials to determine the optimal dose of Sarangsemut plant (Myrmecodia pendens) can be used as a drug to cure lung cancer. The specific objective of this research is to extract Sarangsemut plant (Myrmecodia pendens) and soursop leaves to produce drugs alterlatif cancer disease. Benefits of this research can be used
\end{abstract}


directly by the public to be used as an herbal alternative medicine, to treat cancer .Testing is done by creating a model of lung cancer cells from rats induced with Dimethylbens (a) anthracene as much as 10 times the dose of injection oral 20mg/kgBW. Therapy is done by adding extracts Sarangsemut with different doses each of $250 \mathrm{mg} / \mathrm{kg}$, and $750 \mathrm{mg} / \mathrm{kgBW} 500 \mathrm{mg} / \mathrm{kgBW}$. Based on the test Histopathology showed that lung organ inflammation that leads to cancer. Giving $750 \mathrm{mg} / \mathrm{kgBW}$ Sarangsemut extract can improve lung cells that had suffered necrosis.

\section{Keywords : Sarang semut, Histopathology, lung cancer}

\section{Pendahuluan}

Kanker merupakan suatu tumor atau neoplasma atau neoblastama, yang terdiri dari tumor jinak (benign, benigna) dan tumor ganas (malignant, maligna, kanker). Kanker dapat tumbuh dari jenis sel apapun dan di dalam jaringan tubuh manapun, bukan suatu penyakit tunggal tetapi merupakan sejumlah besar penyakit yang digolongkan berdasarkan jaringan dan jenis sel asal(Anoymous, 2010).

Kanker merupakan masalah besar di dunia. Setiap tahun dijumpai hampir 6 juta penderita baru yang diketahui mengidap kanker, dan lebih dari 4 juta diantaranya meninggal. Kematian akibat kanker mencakup 10\% dari jumlah total kematian. Separuh dari mereka yang terserang kanker, dan dua pertiga dari mereka yang meninggal akibat kanker, berada di negara berkembang. (Kardinan, 2003: hal.12).Hingga kini pengobatan neoplastik atau kanker dapat dilakukan dengan dengan 3 cara yaitu: pembedahan, radiasi, dan dengan pemberian obat anti neoplastik atau anti kanker. Pengobatan tumor bronkial jinak biasanya diangkat melalui pembedahan karena bisa menyumbat bronki dan lama-lama bisa menjadi ganas tetapi pembedahan tidak selalu membawa kesembuhan. Terapi penyinaran dilakukan pada penderita yang tidak dapat menjalani pembedahan karena mereka memiliki penyakit lain yang serius. Tujuan dari penyinaran adalah memperlambat pertumbuhan kanker, bukan untuk penyembuhan. Terapi penyinaran juga bisa mengurangi nsyeri otot, sindroma vena kava superior dan penekanan saraf tulang belakang. Tetapi terapi penyinaran bisa menyebabkan peradang paru-paru (pneumonitis karena penyinaran), dengan gejala berupa batuk, sesak nafas dan demam. Gejala ini bisa dikurangi dengan kortikosteroid . Pada saat terdiagnosis, karsinoma sel kecil hampir selalu telah menyebar ke bagian tubuh lainnya, sehingga tidak mungkin dilakukan pembedahan.(PDPI,2003).

Ketiga cara pengobatan diatas banyak member-kan efek samping kepada pasien sepetri terjadi komplikasi, dan penekanan fungsi sumsum tulang. Kenyatan tersebut menuntut perlunya cara alternatif yang aman untuk memberantas kanker dengan menggunakan bahan alami,

Sarang semut yang merupakan tanaman asli Indonesia, mengandung senyawa Flavonoid, Tanin, dan Poliefenol yang berfungsi sebagai antioksidan dalam tubuh (Subroto, Ahkam dan Hendro Saputro, 2008). Kemampuan Sarang Semut secara empiris dapat mengobati berbagai jenis kanker/tumor dimana bahan dasarnya menggunakan tanaman asli Indonesia.

Secara ekologi, tumbuhan sarang semut tersebar dari hutan bakau dan pohon-pohon di pinggir pantai hingga ketinggian $2.400 \mathrm{~m}$ di atas permukaan laut (dpl).Tumbuhan sarang semut jarang ditemukan di hutan tropis dataran rendah, tetapi lebih banyak ditemukan di hutan dan daerah pertanian terbuka dengan ketinggian sekitar $600 \mathrm{~m}$ dpl (Ahkam \& Hendro, 2008). Di habitat liarnya, tumbuhan sarang semut dihuni oleh beragam jenis semut. Namun, satu tumbuhan sarang semut hanya dihuni oleh satu jenis semut dari genus Iridomyrmex. Sebagai contoh, tumbuhan sarang semut Myrmecodia pendens Merr. \& Perry dihuni oleh koloni semut dari jenis Ochetellus sp. Dalam umbi sarang semut juga ditemukan dua spesies jamur ketika dihuni oleh 
simbion I. cordatus (Ahkam \& Hendro, 2008).

\section{Metode Penelitian}

Secara garis besar penelitian dilakukan dengan dua tahap, tahap pertama melakukan ekstraksi Sarangsemut dengan pelarut metanol dan dipartisi menggunakan pelarut butanol-air dengan perbandingan 1:1. Tahap kedua kedua melakukan uji praklinis ekstrak Sarangsemut fraksi air dengan menggunakan hewan uji tikus putih. Tikus dibagi lima kelompok. Kelompok 1 kontrol, kelompok 2 sampai 5 dijadikan model kanker Paru dengan cara diinduksi dengan Dimethylbens (a)anthracene (DMBA). Kelompok 1 diinjeksi oral dengan minyak jagung, kelompok 2-5 diinjeksi dengan DMBA dosis $20 \mathrm{mg} / \mathrm{kgBB}$ sebanyak 10 kali injjeksi. Kelompok 2 setelah 10 kali injeksi dilakukan nekropsi jaringan dan pengamatan Histopatologi jaringan. Kelompok 3-5 dienjeksi dengan ekstrak Sarangsemut dengan dosis masing-masing $250 \mathrm{mg} / \mathrm{kgBB}, 500 \mathrm{mg} / \mathrm{kg}$ BB dan 750 $\mathrm{mg} / \mathrm{kg} \mathrm{BB}$, masing-masing sebanyak 10 kali injeksi oral. Setelah genap 10 kali injeksi semua tikus dilakukan pengamatan makroskopi (nekropsi) dan mikroskopi (histopatologi).

\section{Hasil dan Pembahasan \\ Uji Makroskopi}

Uji makroskopi dilakukan dengan pembedahan (nekropsi). Dari uji ini secara makroskopi dapat diidentifikasi oragn-organ tubuh tikus yang mengalami kelainan, terutama paru. Secara makroskopi dapat diketahui dapat diketahui organ yang mengalami kelainan. Dari uji makroskopi dapat diprediksi sejauh mana senyawa DMBA dapat menimbulkan kelainan pada organ tubuh tikus.

Hasil uji makroskopi tikus kontrol maupun tikus yang diinduksi dengan DMBA disajikan pada gambar 1.

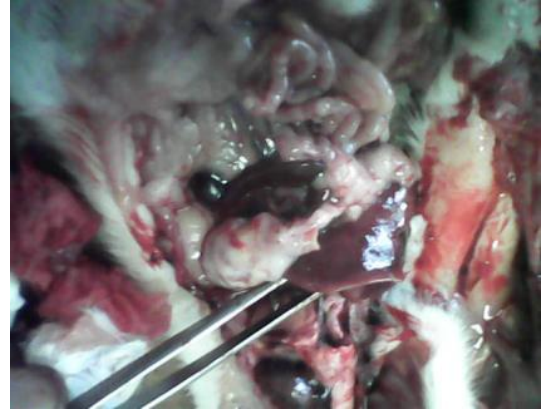

Gambar 1. Hasil nekropsi tikus normal dan sudah diinduksi dengan DMBA

Dari gambar diatas dapat dikemukakan bahwa tikus yang telah diinjeksi peroral dengan DMBA tidak hanya Paru-parunya tetapi organ lever maupun ginjal telah terinfeksi. Secara farmakologi oragan yang pertama kali terinfeksi adalah ginjal, diikuti oleh hati dan paru. Nampak paru yang terinfeksi terjadi penebalan, diindikasikan paru telah mengalami peradangan yang mengarah kepada kanker. Sejauh mana peradangan yang timbul akan dapat dijelaskan secara mikroskopi jaringan.

\section{Uji Mikroskopis}

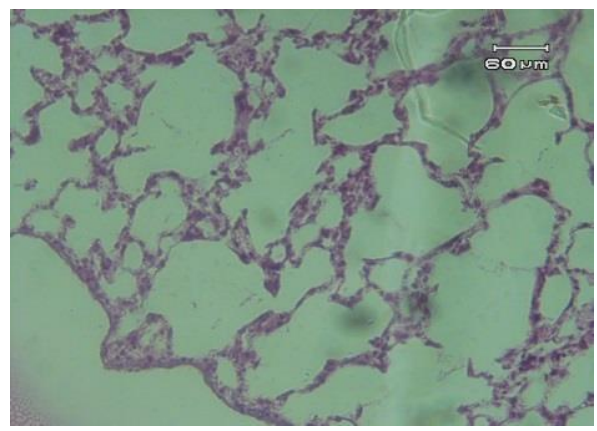

Gambar 2 : Sel paru tikus normal

Dari gambar diatas nampak bahwa paru dalam keadaan normal, artinya tidak ada penebalan alveolus, nekrosis tidak terjadi pada alveolus. Tidak ada penebalan septa maupun konggesti. Sedang sel paru yang diinduksi dengan DMBA disajikan pada gambar 3 . 


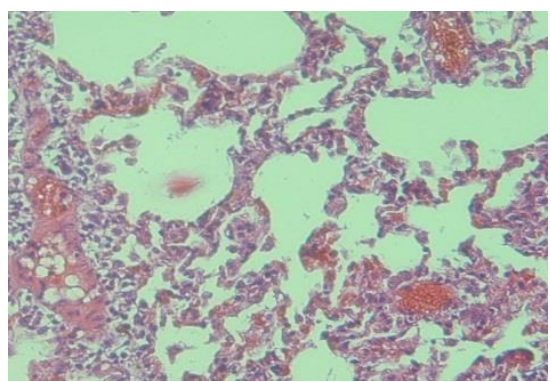

Gambar 3 : Sel Paru yang diinduksi dengan DMBA Dosis $20 \mathrm{mg} / \mathrm{kgBB}$

Dari gambar 3 nampak adanya penebalan pada septa alveolus hal ini diduga peradangan periatritis sebagai awal terbentuknya kanker. Dari gambar ini nampak konggesti diluar alveolus (merah) hal ini menandakan sirkulasi darah tidak lancar. Nampak terjadi nekrosis, hal ini nampak adanya massa diluar alveolus. Nekrosis ini diakibatkan adanya senyawa DMBA yang diinduksikan. DMBA merupakan zat karsinogen yang dibioaktivasi oleh enzim sitokrom P450 menjadi senyawa epoksid yang bersifat reaktif untuk berukatan dengan DNA (Wulan PR,dkk, 2012)

Hasil terapi menggunakan ekstrak sarangsemut berbagai konsentrasi, dapat dilihat pada hasil mikroskopi berikut :

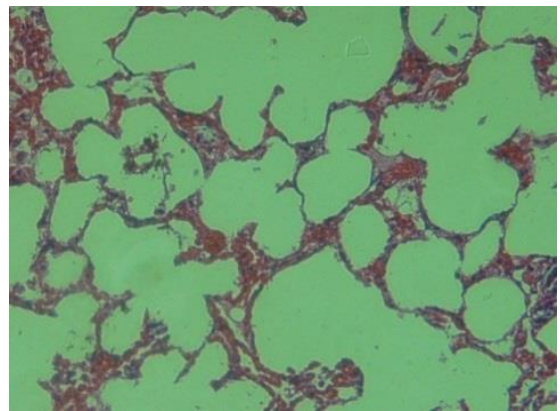

Gambar 4 : Paru tikus yang diinduksi DMBA dosis $20 \mathrm{mg} / \mathrm{kg}$ BB dan diterapi dengan ekstraks sarangsemut dosis 250 $\mathrm{mg} / \mathrm{kg}$ BB sebanyak 10 kali injeksi oral

Dari gambar diatas dapat dinyatakan bahwa pada terapi dengan ekstrak Sarang semut dosis $250 \mathrm{mg} / \mathrm{kgBB}$ masih belum memperbaiki sel paru. Hal ini nampak masih adanya konggesti pada septa alveolus, penebalan pada alveolus dan adanya massa sebagai akibat terjadinya hemoragi pada alveolus.

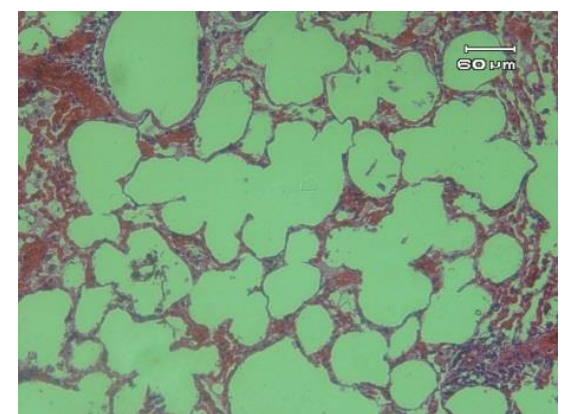

Gambar 5 : : Paru yang diinduksi DMBA dosis $20 \mathrm{mg} / \mathrm{kg} \mathrm{BB}$ dan diterapi dengan ekstraks sarangsemut dosis $500 \mathrm{mg} / \mathrm{kgBB}$ sebanyak 10 kali injeksi oral

Dari gambar 5 diatas dapat dinyatakan bahwa masih terjadi penebalan pada alveolus dan masih ada konggesti pada elveolus walaupun sedik berkurang, namun secara umum sudah mengalami perbaikan. Hal ini berarti masih perlu dilakukan penambahan konsentrasi ekstrak sarangsemut lagi. Sedang terapi menggunakan ekstrak Sarang semut dengan dosis $750 \mathrm{mg} / \mathrm{kgBB}$ disajikan pada gambar 6 .

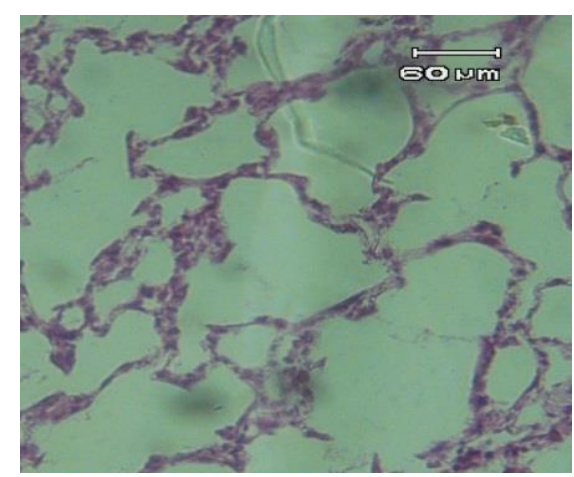

Gambar 6 : Sel paru yang diinduksi DMBA dosis $20 \mathrm{mg} / \mathrm{kg}$ BB dan diterapi dengan ekstraks sarangsemut dosis 750 $\mathrm{mg} / \mathrm{kg}$ BB sebanyak 10 kali injeksi oral

Dari gambar 6 dapat dinyatakan bahwa sel paru tikus sudah banyak mengalami perubahan. Perubahan ini menjurus kearah bentuk normalnya. Keadaan ini membuktikan bahwa pada dosis $750 \mathrm{mg} / \mathrm{kg}$ BB sudah mampu memperbaiki sel paru yang mengalami kerusakan. Secara umum dapat dinyatakan bahwa pada dosis $750 \mathrm{mg} / \mathrm{kgBB}$ ekstrak sarang semut dapat memperbaiki sel paru yang telah mengalami kerusakan akibat induksi DMBA. Perbandingan antara sel 
paru normal, yang sudah terinfeksi dan sel paru yang sudah mengalami perbaikan setelah pemberian ekstrak sarangsemut disajikan dalam gambar 7 .
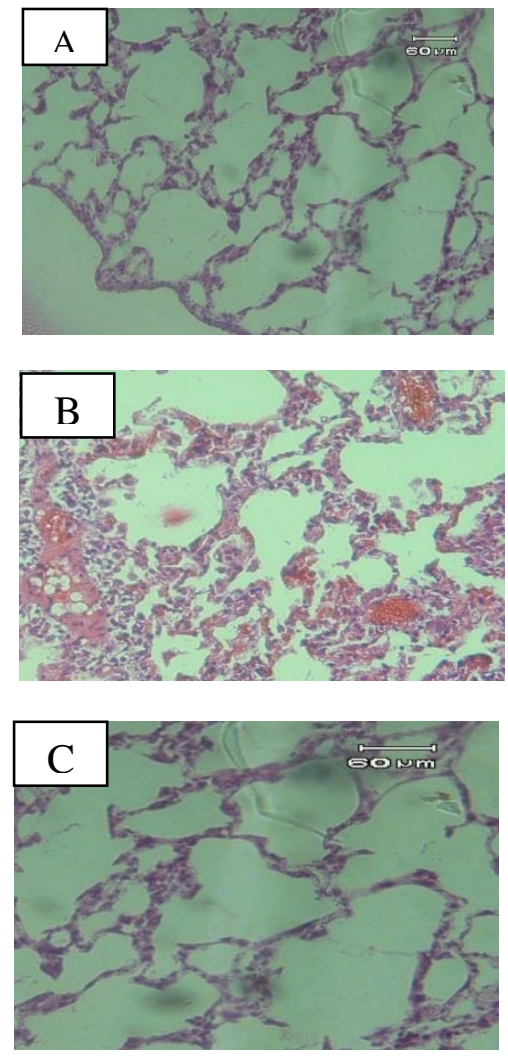

Gambar 7 : Perbandingan hasil histopatologi sel paru.

Dari gamabar A,B dan C dapat dinyatakan bahwa dosis $750 \mathrm{mg} / \mathrm{kg} \mathrm{BB}$ ekstraks sarangsemut dapat memperbaiki sel paru tikus yang telah mengalami kerusakan akibat pemberian DMBA.

\section{Simpulan}

Dari penelitian dapat disimpulkan bahwa dosis $750 \mathrm{mg} / \mathrm{kgBB}$ sarangsemut mampu memperbaiki sel paru yang rusak akibat pemberian DMBA.

\section{Ucapan Terimakasih}

Terimakasih

kepada

DITLITABMAS melalui Kopertis

Wilayah VI yang telah memberikan dana untuk terselesainya penelitian ini dalam skim Hibah Bersaing

\section{Daftar Pustaka}

Anoymous,IC50.http://en.wikipedia.org/ wiki/IC50. Diakses pada tanggal 5 Februari 2010

Belleville-Nabet, F. 1996. "Zat Gizi Antioksidan Penangkal Senyawa Radikal Pangan dalam Sistem Biologis." dalam: Prosiding Seminar Senyawa Radikal dan Sistem Pangan: Reaksi Biomolekuler, Dampak terhadap Kesehatan dan Penangkalan. CFNSIPB dan Kedutaan Besar PrancisJakarta.

Davis M.F, Teresa Y.M. Poultry Necropsy Basics. VME-0012-01.

November 2008

Demple, B. dan L. Harrison. 1994. Annual Review Biochemistry. 63: 915-948.

Ericsson et al.,1978, Fixation in Electron Microscopy in Human Medicine, Vol.1 McGraw-Hill International Book Company, Great Britain.

Friedberg, E. C., G. C. Walker, dan W. Siede. 1995. DNA Repair and Mutagenesis American society and Microbiology. Washington DC.

Harborne, J. B. 1987. Metode Fitokimia Penuntun Cara Modern Menganalisa Tumbuhan. Alih Bahasa: K. Padmawinata. ITB: Bandung.

Hariono B., 2009, Mikroskopi Elektron Pengenalan dan teknik preparasi, hal 17, 20-23, Penerbit Kanisius, Yogyakarta.

Hidaka, K., Matsuda, T. and Takea, T. 1999. "chemical studies on Antioxydant Mechanism of Curcuminoid: Analysis of Radical Reaction products from Curcumin, Jurnal Agriculture and Food Chem, Vol. 47.

McCord, J. M. 1979. "Superoxide, Superoxide Dismutase and Oxygen Toxicity." dalam: Reviews in Biochemical Toxicology. E. Hodgson, J. R. Bend, R.M. Philpot (Eds.). Elsevier Amsterdam, the Netherlands. p. 109-124.

Subroto, Ahkam dan Hendro, S. 2008. Gempur Penyakit dengan Sarang Semut. Penebar Swadaya: Jakarta. 
Metode Ekstraksi Sarang Semut dengan Teknik Maserasi untuk Menghasilkan Obat Alternatif Kanker Paru

Soeksmanto,A 2010 , Pakistan Journal of Biological Science 13 (3) :I 48151,2010
Winarsi, H. 2007. Antioksidan Alami dan Radikal Bebas Potensi dan Aplikasinya dalam Kesehatan. Kanisius: Yogyakar 